Marquette University

e-Publications@Marquette

Economics Faculty Research and Publications

Economics, Department of

5-1-2008

\title{
The Turn in Recent Economics and Return of Orthodoxy
}

John B. Davis

Marquette University, john.davis@marquette.edu

Accepted version.Cambridge Journal of Economics, Vol. 32, No. 3 (May 2008): 349-366. DOI. (C) 2008 Oxford University Press. Used with permission. 


\title{
The Turn in Recent Economics and Return of Orthodoxy
}

\author{
John B. Davis \\ Department of Economics, Marquette University \\ Milwaukee, WI
}

\begin{abstract}
This paper examines change on the economics research frontier, and asks whether the current competition between new research programmes may be supplanted by a new single dominant approach in the future. The paper discusses whether economics tends to be dominated by a single approach or reflect a pluralism of approaches, and argues that, historically, it has alternated between the two. It argues that orthodoxy usually emerges from heterodoxy, and interprets the division between orthodoxy and heterodoxy in terms of a core-periphery distinction. Regarding recent economics, the paper maps out two different types of combinations of new research programmes as being synchronic or diachronic in nature. It treats the new research programmes as a new kind of heterodoxy, and asks how a new orthodoxy might arise out of this new heterodoxy and traditional heterodoxy. It discusses this question by advancing two views regarding how to different types of combinations in the new research programmes might consolidate along the lines of three shared commitments with traditional heterodoxy to form a new orthodoxy in economics.
\end{abstract}

Keywords: Recent economics, Orthodoxy, Heterodoxy, Core-periphery 
NOT THE PUBLISHED VERSION; this is the author's final, peer-reviewed manuscript. The published version may be accessed by following the link in the citation at the bottom of the page.

\section{I ntroduction}

It has recently been argued that mainstream economics is in a process of transformation driven by the emergence of a collection of new research programmes over the last two decades all of which make important departures from standard neoclassical economics (Colander, 2000; Colander et al., 2004; Davis, 2006). These new research programmes-including classical game theory, evolutionary game theory, behavioural game theory, evolutionary economics, behavioural economics, experimental economics, neuroeconomics and agent-based complexity economics-currently exhibit considerable heterogeneity, reflecting their separate origins primarily in different sciences outside economics and their pursuit by relatively distinct communities of researchers within economics. This development might consequently be taken as evidence that economics is becoming more pluralistic, perhaps under the impact of a 'reverse imperialism' (Frey and Benz, 2004). But areas of overlap and shared concerns between these new approaches are becoming increasingly evident, creating the possibility of a new general research programme for economics that would abandon much of neoclassicism. Thus, the proliferation of new approaches in economics may reflect a transitional state of affairs, which may give way to new orthodoxy and a new mainstream in the future rather than a more pluralistic economics. This paper investigates how this new orthodoxy could develop, and how it could reconstitute the relationship between orthodoxy and heterodoxy in economics.

This investigation, however, begins with a prior question, namely, whether economics should even be expected to develop a new orthodoxy, and thus produce a new division between orthodoxy and heterodoxy. Why might economics not simply become more pluralistic for the indefinite future? While my own prescription for economics is that it ought to become more pluralistic and remain so, here I attempt to provide a description of the current trend of development in economics as I see it from the perspective of my reading of the history of economics. Accordingly Section 2 first argues that economics has historically tended to alternate between periods in which a single approach is dominant and periods in which there exist a pluralism of approaches, and thus that the field recurringly tends to structure itself 
around dominant research programmes, which indeed also tend to break down, to subsequently be replaced by a pluralism of approaches, which then in turn give way again to dominant approaches. In order to lay a basis for examination of the current state of affairs in the mainstream, the discussion then proceeds to an analysis of why economics the former phase, or why economics tends to abandon periods of pluralism to structure itself around dominant programmes. Section 3 turns to the related issue of the nature of orthodoxy and heterodoxy in economics. I define these terms, argue that the relationship between orthodoxy and heterodoxy in economics is regularly reconstituted across the field's history, and also argue that orthodoxy usually emerges from heterodoxy. Following these arguments I represent the relationship between orthodoxy and heterodoxy in economics as a core-periphery relationship, and then give a taxonomy of heterodox approaches in terms of their respective origins and orientations. Section 4 then moves to the current state of affairs in mainstream economics, and maps out two different types of combinations of new research programmes characterised as either synchronic or diachronic in orientation. I argue that all the new mainstream research programmes maintain fundamental assumptions strictly at odds with neoclassical orthodoxy and more consonant with heterodoxy. Section 5 goes on to compare the new research programmes with traditional heterodox research programmes, and asks how a new orthodoxy might arise out of heterodoxy in general. Three shared commitments between the new programmes and traditional heterodoxy are identified as a potential basis for a new orthodoxy. Section 6 advances two views-one more conservative and one more transformational-regarding how the new research programmes might consolidate around their three shared commitments with traditional heterodoxy to form a new orthodoxy in economics. Section 7 closes with brief comments regarding economics' relative autonomy as a field.

\section{Dominance and pluralism in economics}

It is beyond the scope of this paper to fully review the relationship between dominant approaches and pluralism in the history of economics, but consider the nature of five generally accepted periods of pluralism in economics: the transition from classical to 
neoclassical economics in nineteenth-century Britain (Peart and Levy, 2005); the Methodenstreit between the German Historical School and the early Austrians (Anderson et al., 1992); the multiple approaches to labour and monetary economics in post-Marshall Cambridge (Lawlor, 2007); the interwar competition in the USA between institutional and neoclassical economics (Morgan and Rutherford, 1998); and the 1970s debate between proponents of monetary and fiscal policy in the ISLM framework (Young, 1987). In each case we find a that a pluralistic environment succeeded a period in which a single approach was dominant, and also find that this pluralistic environment later gave way to a new dominant approach. Neither pluralism nor dominance, then, appears to be a permanent state of affairs, and though each persists for periods of time, each is also ultimately replaced by the opposite state of affairs. It would be too simple to say that economics displays anything on the order of regular cycles of pluralism and dominance over its history, especially given the many interacting levels on which it (as any other subject) develops, but it might not be too much to argue that dominant research programmes create conditions for their subsequent fragmentation, whereas periods of pluralism create conditions for the re-emergence of new dominant approaches. ${ }^{1}$ This does not mean that it is always clear which state of affairs obtains. Within heterodox economics itself, the current state of affairs is clearly pluralistic, and yet some have recently argued there are a number of shared principles and commitments among the different heterodox approaches that might lay the basis for a single dominant conception of heterodoxy (Lawson, 2006; Lee, 2006). Within mainstream economics the situation is less clear, particularly given current neoclassical dominance of pedagogy, though the research frontier is clearly more heterogeneous than it was two decades ago, and debate has now also begun over possible components of a postneoclassical single mainstream approach in economics (Gintis, 2007). ${ }^{2}$

Beyond the evidence that economics alternates between dominant approaches and pluralism, why else might we expect periods of pluralism to be succeeded by periods in which single approaches are dominant? One way to examine this question is to compare economics to its immediate neighbours-other social sciences-and here I draw on an extensive literature from the sociology of scientific knowledge regarding symbolic boundaries between sciences and academic disciplines that investigates how different sciences and disciplines rely 
on different systems of internal organisation to promote their relative autonomy vis-à-vis one another. ${ }^{3}$ Thus, most social science fields, such as psychology, sociology, political science, and anthropology, are basically divided between what is internally seen as the conventional approach to the field and a collection of unconventional approaches, and professional legitimation in the field is strongly associated with pursuing the former. The stronger term 'orthodox', although used in economics, is not commonly associated with conventional approaches in other fields; nor is the term 'heterodox' as common elsewhere. But the literature as a whole generally argues that academic and professional disciplines recurringly structure themselves around dominant approaches on the grounds that this enables individuals within those fields to organise themselves in coherent (academic or professional) social groups, which then maintain themselves relative to similar (academic or professional) social groups that potentially may lay claim to their research domains.

Why, then, does economics employ the stronger language of 'orthodoxy' and 'heterodoxy?' One line of argument in this general literature emphasises differences between fields' social policy exposure. In the domain of policy, fields must justify their value to the non-specialist public, whereas their internal constitution around the conventional/unconventional divide is a matter of structuring themselves to maintain their disciplinary boundaries (though the two defences are related). If we then classify sciences from a policy perspective as (i) high uncertainty and high stakes, (ii) high uncertainty and low stakes, (iii) low uncertainty and high stakes and (iv) low uncertainty and low stakes, because of the wide scope and profound impact of the market in modern society, and because economics' policy forecasts are often unreliable at both the micro and macro levels, economics falls into the first category of high uncertainty and high stakes. In effect, economics, might be considered an example of what has been called 'post-normal' science (contra Thomas Kuhn), where considerable uncertainty exists about the consequences of its policy application, there is weak consensus regarding the science's underlying values, and the stakes associated with policy error are high (Funtowicz and Ravetz, 1992; Ravetz, 1986; also cf. Reay, 2006). My claim, then, is that one important reason economics uses the language of 'orthodoxy' and 'heterodoxy' is that this provides a defence against the public criticism that is inevitable in high uncertainty, high stakes 
circumstances. Essentially, the orthodoxy-heterodoxy distinction allows economics to claim economics is scientific by dismissing heterodoxy as unscientific. This requires that economics institutionalise visible discriminatory practices against heterodoxy (cf. Lee, forthcoming), though arguably not eliminate it entirely, since otherwise the identification of orthodoxy with science is not sustained. That is, eliminating heterodoxy eliminates orthodoxy. This enables economics to draw on the general esteem in which science is held in modern society to limit criticism of failed policy. Moreover, this defence is indirect in nature-and thus more subtle-because it avoids open promotion of orthodoxy by emphasising instead the policing of heterodoxy. ${ }^{4}$

The need for economics to maintain its status as a science suggests yet another reason why we should expect periods of pluralism to be succeeded by periods in which single approaches are dominant that, in this instance, relies not on comparing economics to its close neighbours, other social sciences, but on comparing it to the highly regarded natural and physical sciences. I explain this in terms of two important respects in which economics differs from the natural and physical sciences. First, many of the latter employ controlled experiment to generate laboratory data to evaluate scientific hypotheses, whereas until quite recently economics has depended upon less reliable non-experimental field data for the empirical verification of theory. Second, while all sciences, including the experimental sciences, are value laden to some degree, valueladeness plays a significantly larger role in economics than it does in these other sciences by virtue of the closer proximity of economics to human interests. This latter difference, I suggest, is the more important one, since many would say that bias, such as that which value-ladeness can produce, is a worse problem than having to work with non-experimental field data. Indeed the natural and physical sciences that use non-experimental data are generally seen as less vulnerable to bias than economics. The implication of these two points, accordingly, is that, given the character of its empirical practice, economics first and foremost needs to minimise the appearance of value-ladeness to maintain its status as science.

Note, then, that in a pluralistic economics differences in value assumptions between different approaches are readily apparent, 
making the larger role value judgements play in economics as a whole more transparent. In contrast, when a dominant programme is in place, since it tends to be identified with the science as a whole, value judgements are more likely to be taken for granted and, as a result, are less frequently articulated. Thus, the main problem associated with seeing economics as a science vis-à-vis natural and physical science disappears from view. At the same time, an absence of pluralism also reduces debate about empirical practice, so that economics' differences with natural and physical science also attract less attention. Indeed the issue of economics' standing as a science has recently become more prominent with the rise of experimental economics, and repeated pronouncements of experimentalists and many others that economics' long history as a largely a priori deductive science exhibits questionable scientific credentials (e.g. Samuelson, 2005; Smith, 1989, 1994). Thus, altogether pluralism generates doubts about economics' standing as a science, whereas dominant approaches tend to reduce these doubts.

For these reasons, then, pluralism in economics tends to give way to dominant approaches, even if those dominant approaches ultimately later give way again to pluralism. Consequently, despite an increasing pluralism on the mainstream economics research frontier, the subject's history and its relative standing as a scientific discipline among other disciplines give us good reason to anticipate the formation of a new dominant approach. It is important to emphasise, however, that across the history of economics succeeding dominant approaches have had surprisingly little resemblance to each other. That is, the dominant approach that follows a period of pluralism seems to little resemble the dominant approach that preceded that period of pluralism. For example, classical economics was preceded by physiocracy and mercantilism, and succeeded by neoclassicism. Although there exist continuities between all three, most historians would agree that they represent fundamentally different approaches. I suggest that in the history of economics, then, the non-replication of dominant approaches generally holds true. Thus, the possible emergence of a new dominant approach in mainstream economics is more likely than not to be substantially different from neoclassical economics. Two further reasons to expect this are that all the new research programmes in economics have their origins primarily in other sciences, and thus import new assumptions and concepts into 
NOT THE PUBLISHED VERSION; this is the author's final, peer-reviewed manuscript. The published version may be accessed by following the link in the citation at the bottom of the page.

economics, and all challenge fundamental assumptions in neoclassicism. ${ }^{6}$ However, before turning to what consolidations between these new approaches might emerge, the following section addresses the nature of the orthodox-heterodox divide in current economics.

\section{The orthodox- heterodox divide in economics}

The terms 'orthodox' and 'heterodox' have been used in a variety ways in economics, but in the discussion above they are treated as sociological terms that define what is generally regarded as conventional or unconventional in the economics. ${ }^{7}$ There are two important implications of this interpretation. First, neither 'orthodox' nor 'heterodox' inherently refers to any particular type of approach in economics; alternatively, any kind of approach in economics can be orthodox or heterodox depending on historical conditions, and indeed in the history of economics most major approaches have been both at one time or another, and not infrequently both at the same time, though in different locations. ${ }^{8}$ Second, though there has often been a close correlation between individual economists' professional success and their association with conventional approaches, this has tended to be more (though not exclusively) the case when a dominant approach exists, whereas in periods of pluralism, when what is conventional is unclear or under challenge, many individuals can be quite successful professionally though their approaches are still unconventional. For example, today both behavioural and experimental economics are not conventional, though many of their main contributors are very successful professionally, as evidenced by the Nobel prizes awarded to Daniel Kahneman and Vernon Smith. This creates problems for explanations of the orthodox-heterodox divide in economics, since the term 'mainstream' is both typically applied to those who are professionally successful, and is also equated with the term 'orthodox.' The professional success of many behavioural and experimental economists tells us that the first meaning ought to be retained, but the fact that these approaches are not conventional tells us that the second meaning should not.

However, this creates a further problem for the interpretation of the terms 'orthodox' and 'heterodox', namely, if approaches such as

Cambridge Journal of Economics, Vol 32, No. 3 (May 2008): pg. 349-366. DOI. This article is (C) Oxford University Press and permission has been granted for this version to appear in e-Publications@Marquette. Oxford University Press does not grant permission for this article to be further copied/distributed or hosted elsewhere without the express permission from Oxford University Press. 
behavioural and experimental economics are mainstream yet not conventional, are they heterodox? Many orthodox and heterodox economists would no doubt deny they are, because they associate heterodoxy strictly with being outside the mainstream. Note, however, that two of the new approaches in the mainstream, behavioural and evolutionary economics are also established heterodox approaches and, more recently, heterodox economists have begun to make use of complexity theory. We might still reserve the term non-conventional for the new approaches, but I will argue in the next section that the new approaches all maintain fundamental assumptions at odds with neoclassical orthodoxy, and thus should be seen as heterodox. This would then imply that current heterodoxy juxtaposes approaches many see as quite different, but should this seem an objection, we might note that in the history of economics heterodoxy has often been highly heterogeneous. Indeed, historically, heterodoxy in economics has been more a big tent affair with a variety of disparate approaches usually having few links to one another rather than having been an organised opposition to orthodoxy, as is associated with the contemporary International Confederation of Associations for Pluralism in Economics (ICAPE). Perhaps the most accurate label, then, is 'mainstream heterodox', as odd as this may sound. Some prefer to emphasise 'dissent' as a better label (Backhouse, 2004; Holt and Pressman, 1998), but dissent suggests disagreement within a shared framework, and I take the differences between the new approaches in the mainstream and neoclassicism to be both more radical and indeed close to many positions that traditional heterodoxy has critically advanced against neoclassicism. The next section thus provides a defence of the 'mainstream heterodox' label in terms of these positions, and then Section 5 turns to the issue of what this all implies about the relationship between existing heterodoxy and mainstream heterodoxy.

Returning, however, to the historical relationship between orthodoxy and heterodoxy, I claim that orthodoxy ultimately always emerges from heterodoxy (cf. Coats, 1999). New dominant approaches emerge from periods of pluralism that are preceded by periods with earlier orthodox-heterodox divides. As dominant approaches have not historically replicated themselves across periods of pluralism, new dominant approaches must have their origins in heterodoxy. How, then, might current heterodoxy produce a future permission has been granted for this version to appear in e-Publications@Marquette. Oxford University Press does not grant permission for this article to be further copied/distributed or hosted elsewhere without the express permission from Oxford University Press. 
orthodoxy? To investigate this question, the balance of this section distinguishes between different heterodox approaches in terms of their different origins and orientations, and frames this all in terms of a core-periphery characterisation of the orthodox-heterodox divide.

As befits the postwar period of neoclassical dominance, much thinking about existing heterodoxy is strongly associated with understanding its relation to neoclassicism, and this common opposition suggests that these different approaches have similar origins and orientations. But just as the history of economics shows that orthodoxy arises in different ways, it also shows that different approaches become heterodox in different ways. Further, as some heterodox approaches ultimately become orthodox and others do not, their respective orientations toward orthodoxy should be expected to differ as well. Focusing first on the origins side of the story, I distinguish four different ways in which heterodox approaches arise relative to changes in orthodoxy. Heterodoxy arises because of: That is, different heterodox research programmes have what might be called different 'origin stories', where these stories tell how particular research programmes acquire the status of being heterodox. Though there is considerable room for debate, among the approaches customarily seen to be heterodox I provisionally suggest that the Veblenian evolutionary-institutional approach be seen as an example of (1), post-Keynesianism as the inheritor of J. M. Keynes' economics be seen as an example of (2), the neo-Ricardian approach as reflects Piero Sraffa's thinking be seen as an example of (3), and early feminist economics that engaged the work of Gary Becker be seen as an example of (4). ${ }^{9}$

(1) Failure to become orthodox following a period of pluralism.

(2) Loss of the status of orthodox when a new orthodoxy emerges.

(3) Failure to redirect orthodoxy from outside orthodoxy.

(4) Failure to redirect orthodoxy from inside orthodoxy.

To place these origin stories in a larger framework, let us represent the relationship between orthodox and heterodox approaches in economics as a core-periphery relationship, where the field's core principles and concepts are defined as orthodox and also suppress reference to periphery principles, while the field's heterodox periphery 
is defined in terms of principles and concepts explicitly seen to lie outside the core and yet which also bear some relationship to the boundaries of the field as a whole. For example, a core principle in orthodox neoclassical economics is that individual behaviour is rational, and a common defense of the principle is that 'it could not be otherwise' (thus suppressing reference to other forms of conceptualisation). In contrast, a periphery principle in traditional Marxist economics is that individual behaviour reflects class location. The Marxist explanation is heterodox in virtue of explicitly lying outside the core of the field, but the concept of class also bears a relation to the boundaries of economics in light of its important role in sociology. Two comments on this framework are worth noting. First, though the core-periphery distinction can be used to distinguish orthodoxy and heterodoxy, since nothing in the history of economics is intrinsically orthodox or heterodox, core and periphery principles and concepts can and have exchanged places in the history of economics. Second, it can also be argued that, as the sciences are relatively distinct from one another, over often considerable periods of time, certain principles tend to remain core principles across changes in dominant approaches, even when these arise out of heterodoxy (despite considerable change regarding what else is orthodox). For example, it might be argued that the concept of equilibrium is a core principle in economics, and that challenges to this principle risk breaking down the boundaries of economics as a relatively autonomous discipline. I return to this point briefly in the last section.

In addition to different heterodox approaches' origin stories, then, consider now their different possible orientations. Whereas orthodox approaches are essentially inward-looking, and generally suppress reference to heterodox programmes within their own conceptualisation (if not in their self-defence as science), heterodox approaches can orient more or less toward the field's core or toward the boundaries of economics and other sciences beyond its periphery. Combining these two orientation possibilities with the four different origin stories gives a roughly eight-fold classification of heterodox approaches. Again, of course, classifying any particular individual heterodox approach as one of these eight cases cannot but be controversial. And individual heterodox approaches also exhibit considerable heterogeneity allowing multiple interpretations. As illustrations, however, I suggest examples of two polar cases.

Cambridge Journal of Economics, Vol 32, No. 3 (May 2008): pg. 349-366. DOI. This article is @ Oxford University Press and permission has been granted for this version to appear in e-Publications@Marquette. Oxford University Press does not grant permission for this article to be further copied/distributed or hosted elsewhere without the express permission from Oxford University Press. 
One extreme is an approach that originates as orthodox, but upon becoming heterodox-origin story (2) -turns away from the new orthodoxy to incorporate principles from other sciences, thus, in effect, continually moving from the centre outwards. Post-Keynesian economics, for example, might be considered formerly orthodox (as Keynes's economics before ISLM) and is now heterodox, but, as fundamentally concerned with path-dependency and strong uncertainty, concepts with currently a greater role outside of economics in evolutionary biology and history, could be characterised as oriented outwards toward the boundaries of economics. Or, to take the opposite extreme, there are what I regard as heterodox approaches in economics that originate in other sciences, that is, beyond the field's periphery, and then orient inwards toward the core of economics in an attempt to redirect it, though remaining heterodox unless successful-origin story (3). Current behavioural economics with its origins in psychology and its primary focus as the critique of rational choice has an orientation toward the core of economics and thus seems to be an example of this case.

Whether these classifications are accepted or rejected, I argue that different heterodox approaches can generally be distinguished and characterised according to their respective combinations of different origin stories and primary orientations. What, then, does this imply about current heterodoxy, broadly understood? I claim that all the new mainstream research programmes in economics (evolutionary economics may be an exception) are generally, like behavioural economics, examples of the second extreme above. They all originate outside of economics and are mostly oriented toward redirecting the core of economics. That is, their agenda is to revise the existing core principles in the discipline. The situation is more mixed, however, with those approaches usually recognised as heterodox. Some are oriented toward the field's core, but most, I believe, are oriented more towards the field's boundaries, with the project of broadening or transforming economics as a whole by challenging its boundaries. Consider, for example, the theory of choice as a core doctrine. Behavioural economists think the theory of choice in economics is wrong, but rather than abandon the theory of choice altogether, they want to revise it. Most heterodox economists, however, simply believe the theory of choice should be abandoned for non-individualistic conceptualisations of the economic process that have more in common permission has been granted for this version to appear in e-Publications@Marquette. Oxford University Press does not grant permission for this article to be further copied/distributed or hosted elsewhere without the express permission from Oxford University Press. 
with other social sciences. My point here is not that one approach is better or worse than the other, but that the orientations are different, and this may have significant implications for how economics changes in the future, and a new orthodoxy (and heterodoxy) develops.

\section{Synchronic and diachronic research programmes in recent mainstream economics}

I treat the new research programmes in mainstream economics as largely synchronic or diachronic. Synchronic types of explanations can be defined as those that emphasise the interrelation of particular kinds of phenomena within limited time frames, and diachronic types of explanations can be defined as those that emphasise how phenomena undergo a process of change through time. I do not refer to these two types of explanations as static and dynamic for three reasons. First, to do so would be to assume that these new programmes replicate that same distinction, whereas the history of economics appears to show that this distinction applies specifically to the period in which neoclassical economics is dominant rather than across the history of economics. Second, standard static explanations are general explanations of abstract agents framed mathematically, whereas those approaches I treat as synchronic are ideal-type scenario-driven accounts of particular processes governing the interaction of interdependent agents explicated with a variety of modelling strategies. Similarly, the standard view of dynamics is that it involves investigation of mathematical models that are recursive and deterministic, while the approaches I treat as diachronic explicitly model evolution and change. Third, the static-dynamic distinction does not align nicely with the synchronic-diachronic distinction. For example, game theory, which might be thought of as a characteristically static form of explanation, has one-off games, finitely repeated games, indefinitely repeated games and evolutionary games (cf. Hargreaves Heap and Varoufakis, 2004), whereas agent-based complexity economics, which might be thought of as a characteristically dynamic form of explanation, is populated with simulation models that set up initial conditions that are allowed to run out to sets of determinate (if often unexpected) results (e.g. Kirman, 2001; Tesfatsion, 2001). Indeed, my view is that the synchronicdiachronic distinction, while reasonably adequate as a means of 
classifying the new research programmes today, will stand up less well as these programmes increasingly converge and draw upon one another in the future.

The research programmes employing primarily synchronic forms of explanation (and some leading figures), then, are classical game theory (John Nash, Robert Aumann, John Harsanyi, Reinhard Selten and Ariel Rubinstein), behavioural game theory (Colin Camerer, Ernst Fehr, Werner Guth and Matthew Rabin), behavioural economics (Herbert Simon, Amos Tversky, Daniel Kahneman, Richard Thaler, George Loewenstein, Colin Camerer, J on Elster and Gerd Gigerenzer), experimental economics (Vernon Smith, Selten, David Grether, Charles Plott) and neuroeconomics (Paul Glimcher, Colin Camerer, Paul Zak and Kevin McCabe). The research programmes employing primarily diachronic forms of explanation (and some leading figures) are evolutionary game theory (Thomas Schelling, Robert Axelrod, John Maynard Smith, Ken Binmore and Larry Samuelson), evolutionary economics (Paul David, H. Peyton Young and Douglas North) and agent-based complexity economics (Herbert Simon, Thomas Schelling, John Holland, Brian Arthur, Douglas North, Steve Durlauf, Alan Kirman, Paul Krugman and Leigh Tesfatsion).

Note that some of these 'new' programmes had antecedents in the postwar period that failed to command a significant following, for example, game theory immediately after the war (cf. Mirowski, 2002) and the behavioural economics of Simon and colleagues (cf. Sent, 2004). In addition, some of the individuals mentioned above were active in these new approaches well before they became recognised in the last two decades as identifiable research programmes (e.g. the earlier work of Smith and Schelling). Also, note that the boundaries between the approaches are not always sharp, as reflected in some individuals' involvement in more than one approach. Finally, although these approaches are all new to the mainstream, in varying degrees they all have antecedents in existing heterodox research programmes, which in some instances go back many years. Indeed, this link, generally unacknowledged from both sides, is central to the argument of this paper.

Three of the synchronic programmes, then, classical game theory, experimental economics and behavioural game theory, are 
accounts of agent interaction, whereas two others, behavioural economics per se and neuroeconomics, provide theoretical and empirical foundations for these accounts. All investigate different types of ideal-type scenarios, basically different kinds of games or different auction forms or trading systems (cf. Friedman and Cassar, 2004; Heinrich et al., 2004), in which individuals interact in particular contexts rather than simply solve general parameterised Walrasian optimisation problems (cf. Colander, 1996). Individuals may be selfregarding, other-regarding (Gintis, 2007) and act on the basis of a variety of norms, ethical and otherwise, which may have social or anthropological bases (Camerer and Fehr, 2004). They exhibit a variety of types of behaviour other than optimisation, are boundedly rational and weak of will in various ways, and have preferences that are endogenous in varying degrees, the main debate being whether preferences are constructed (Cubitt et al., 2001) or discovered (Plott, 1996), not whether preferences are exogenous. There is considerable ambivalence and outright doubts about laissez faire and the idea that markets are natural with interventionist calls for 'libertarian paternalism' (Sunstein and Thaler, 2003), and the issue of how to construct markets or market design has moved to the forefront of policy (cf. Guala, 2001; Nik-Khah, 2006).

Behavioural economics (e.g. Camerer and Loewenstein, 2003; Kahneman, 2003; Starmer, 2000) and neuroeconomics (Camerer et al., 2005) offer theories of the foundations of agent behaviour. In both, the axiomatic rationality analysis of neoclassicism is rejected, in the former in light of evidence from psychology and in the latter in light of evidence from neuroscience. Relatedly, though classical game theory treats individuals as rational, the rather mixed success of the equilibrium refinements programme meant to limit the possible Nash equilibria in games (cf. Rizvi, 1994) casts doubt on the degree to which individuals in games can indeed be seen as rational. In contrast, behavioural game theory, arguably now the main avenue forward for game theory, investigates individual behaviour in games empirically rather than simply assume it to be rational (Camerer, 2003). Game theory in general, moreover, rejects neoclassicism's benchmark competitive model of indirect interaction solely through the price mechanism to focus on scenario-driven direct interaction. 
In terms of the core-periphery analysis of orthodox and heterodox from the last section, then, these approaches all exhibit both origin story (3), by virtue of the fact that their concepts, principles and theoretical strategies originate in other sciences, and as described above are also all oriented inward, by virtue of their focus on challenging core neoclassical assumptions and commitments.

Experimentalism, of course, did not exist in economics, except in rare instances, until relatively recently and, by its nature, it contests the a priori form of theorizing characteristic of neoclassicism.

Experimentalism, however, is fundamental in most other sciences. Behavioural economics and neuroeconomics, as noted, originate in psychology and neuroscience, respectively. Game theory was developed initially in mathematics, and intentionally exported to economics for the purpose of transforming it (von Neumann and Morgenstern, 1944). Combined, these different programmes offer an alternative substantive account of individual behaviour as interactive as well as alternative methodologies and methods of investigation.

The new synchronic approaches, then, all maintain fundamental assumptions at odds with neoclassical orthodoxy. What about the diachronic programmes? The three diachronic forms of explanationevolutionary game theory, evolutionary economics and agent-based complexity economics-have even less in common with neoclassicism. Most importantly, whereas the latter employs dynamic models with given agents on deterministic time paths, the new programmes use a biology-based type of modelling with evolving environments in which agents and their relationships change. Evolutionary game theory, the most mathematical (thus perhaps thought the closest to neoclassicism), abandons individuals and methodological individualism altogether to focus on population shares of types of agents or kinds of strategies (cf. Samuelson, 2002). As in classical game theory, agents interact directly in specific contexts, but their interaction can be transformed by the emergence of unforeseeable strategies and 'mutant' agents. In non-game theoretic evolutionary approaches, institutional structures condition and are generated by lock-in, network externalities and path dependence (David, 1985, 2005; North, 2004). Complexity approaches employ bounded rationality and coevolving expectations of heterogeneous agents to explore different systems of agent interaction (Arthur et al., 1997). All of this is incompatible with 
the neoclassical static conception of atomistic individuals with exogenous preferences.

These diachronic approaches also exhibit origin story (3), particularly in light of the strong influence of biological reasoning and, in the case of complexity approaches, additional influences from physical science and cognitive science (Clark, 1997; Holland, 1995). Essentially these programmes all have their origins outside of economics. The situation with respect to orientation, however, is not as clear as it is with respect to the new synchronic research programmes. While the intention to substitute direct interaction for indirect Walrasian interaction and general recourse to bounded choice indicates a focus on changing economics' core, evolutionary reasoning itself has little basis in neoclassicism, ${ }^{10}$ and thus arguably these diachronic programmes are more concerned with expanding the boundaries of economics and are thus oriented toward the periphery of economics. I return to this issue below, in Section 6, where I address two possible scenarios for the consolidation of economics around a new orthodoxy. But in Section 5 I first discuss the relationship between the new mainstream heterodoxy and traditional heterodoxy.

\section{Mainstream heterodoxy and traditional heterodoxy}

The general argument advanced here is that orthodoxy emerges from heterodoxy. But this includes the possibility that a future orthodoxy in economics might emerge from a combination of heterodox approaches, thus inviting us to address the relationship between the new mainstream heterodoxy and traditional heterodoxy. The main traditional heterodox programmes are generally said to be: (old) institutional economics, Marxist economics (and radical economics), post-Keynesian economics, neo-Ricardian economics, social economics and socio-economics, Austrian economics, feminist economics, critical realism, and post-modernist economics. ${ }^{11}$ In terms of the sociology of economics, there seem to be five important differences between these and other traditional heterodox groups and the new mainstream approaches. 
One difference between them is that the traditional programmes have become heterodox in different ways or have different origin stories, while the new programmes are all heterodox in virtue of their recent emergence in economics from locations outside the field. A second difference is that many of the former tend to be oriented toward the periphery of economics as reflected in a rejection of core orthodox principles rather than pursuit of their reform, combined with an advocacy of alternative foundations for economics based on closer ties to, and less sharp boundaries with, sociology, history, politics and anthropology. There are important exceptions to this judgement (for example, neo-Ricardian economics), but I believe it is shared by most of the recent commentators on traditional heterodoxy (e.g. Backhouse, 2000; Dow, 2000; Lawson, 2006; Lee, 2006). A third difference, as noted above, is that mainstream heterodoxy enjoys the professional advantages of the mainstream. A fourth difference concerns attitudes toward dominance and pluralism in economics. Whereas most traditional heterodox economists reject the idea that economics should have a dominant programme, and embrace the idea that economics should be pluralistic, ${ }^{12}$ most mainstream heterodox economists-as reflects their mainstream professional location and their orientation on the field's core-accept the idea that economics tends to be dominated by single approaches. A fifth difference concerns attitudes toward methods and methodological practice, specifically formal modelling and positivism. Indeed, while some see this as a fundamental dividing line between orthodoxy and heterodoxy (e.g., Backhouse, 2000; Lawson, 1997), most individuals in the new mainstream approaches see the issue as a matter of which more or less formal methods are best rather than whether such methods play too large a role in economics.

Given these differences, if sociological factors were to prevail, prima facie it seems more likely that future orthodoxy in economics will result from a combination of the new mainstream research programmes rather than a combination of those and traditional heterodox approaches (much less the latter alone). Reinforcing this conclusion is the very limited communication between proponents of the new and traditional heterodox research programmes (though recently there have been links from both sides between those favouring behavioural, complexity and evolutionary approaches). Despite this, we might also place weight on the fact that the new mainstream approaches reject many of the fundamental doctrinal 
assumptions of neoclassicism, and ask whether possible agreement over the content of economics might generate greater congruence between the new and traditional heterodox research programmes than sociological factors suggest. To investigate this possibility, I identify three substantive principles, which I suggest characterise the main concerns of most of traditional heterodoxy and constitute critiques of neoclassicism (cf. Davis, 2007), and ask what roles they play in the new mainstream approaches. These three principles are: Each of these principles operates in the new mainstream approaches taken as a set, but, it should be emphasised, each does not operate in each and every one of those approaches. Thus, whether an alignment between the new approaches and traditional heterodoxy may possibly emerge in the future to produce a new orthodoxy in economics seems to depend in good part on how these principles come to be embraced across the new mainstream heterodoxy as a whole. I turn, then, to two possible pathways by which this might occur.

1. Individuals are socially embedded rather than atomistic.

2. Processes are evolutionary rather than mechanical.

3. Individuals and social-economic structures are mutually influencing.

\section{Two pathways to a new orthodoxy}

Distinguishing the synchronic and diachronic research programmes, the five synchronic research programmes appear to be primarily concerned with the first and third issues above, whereas the three diachronic research programmes appear to be primarily concerned with the second and third issues. Regarding the shared third issue, while it is not difficult to see that diachronic approaches emphasising evolution and change have as a fundamental assumption that individuals and social-economic structures are mutually influencing, perhaps it is less obvious with respect to the synchronic approaches. But to take the two 2002 Nobel prize winners as representative, the idea is indeed fundamental to the Kahneman's bounded rationality framing argument in the simple idea that context influences choice (Kahneman, 2003) and to experimentalist Vernon Smith's 'environment-institutions-behaviour' triad and slogan that 'institutions matter' (Smith, 1989). Indeed both behaviouralists and 
experimentalists generally accept the idea of a two-way street between individual behaviour and social-economic structures, and have recently found further common ground in behavioural game theory's cross-cultural experimental examination of how social rules and choices in different societies interact (Heinrich et al., 2004). It is not to be denied that, in comparison with traditional heterodoxy, this principle operates in a more formal and positivistic manner. But it is important to recognise that the substantive position itself is the same as that in traditional heterodoxy. Or, to put matters critically, both the new mainstream approaches and traditional heterodoxy reject the neoclassical one-way street microfoundations view.

While the three diachronic programmes are primarily concerned with the second and third issues, they hardly regard individuals as atomistic, as reflected in the idea that individuals and social structures are mutually influencing. But the status of individuals seems to be a secondary focus in these programmes, with greater attention being devoted to the interaction of different kinds of agents in evolutionary processes. ${ }^{13}$ Thus, the two kinds of new mainstream approaches specialize, as it were, on the first and second principles above, while sharing the third. That is, synchronic approaches take individuals to be socially embedded rather than atomistic, and largely ignore the issue of whether economic processes are evolutionary, while diachronic approaches do the reverse.

On the basis of this difference, I map out two pathways-one more conservative and one more transformational-regarding how a new future orthodoxy might arise in economics. The two pathways are differentiated according to the degree of departure they make from current neoclassical orthodoxy. The main difference between them concerns the weight given to the new diachronic programmes' specialisation and primary concern with processes of change. Current neoclassical orthodoxy exhibits almost no concern with genuine processes of change. A new conservative orthodoxy, then, would essentially emphasise the two commitments of the synchronic programmes, and de-emphasise the primary commitment of the diachronic programmes. On the other hand, a new transformational orthodoxy would combine all three commitments and make a more significant departure from neoclassicism in seeing the economic process as evolutionary. Further, on the transformational pathway, the permission has been granted for this version to appear in e-Publications@Marquette. Oxford University Press does not grant permission for this article to be further copied/distributed or hosted elsewhere without the express permission from Oxford University Press. 
combination of all three commitments in a single programme would presumably produce a stronger interpretation of the two principles specific to the synchronic programmes.

Specifically, consider the kinds of commitments a new orthodoxy might make to principles one and three on the more conservative view. Regarding the first principle, while individuals could, in principle, still be seen to be 'socially' embedded, this would be true in only the most abstract sense were it not framed by some account of how individuals' social embeddedness reflected a changing economic environment. For example, behavioural economics treats individuals as 'socially' embedded rather than atomistic via its heuristics of choice critique of standard theory's independence axiom, but this only takes us as far as the simple idea that the context of choice matters. Regarding the third principle, individuals and socialeconomic structures can still be seen to be mutually influencing, but the idea of social-economic structures could again be highly abstract and formal. For example, the commitment that the experimental economics of Vernon Smith and others makes to the mutual influence idea-'institutions matter'-essentially compares the designs of different alternative market institutions in their effects on choice from the perspective of the expert, and tells us little about how the two-way street relationship between institutions and individuals actually works in an historical world governed by change. ${ }^{14}$

A new orthodoxy, then, could distinguish itself from neoclassical orthodoxy by its mild adoption of principles one and three and general neglect of principle two, and thus remain conservative in terms of the limited departure this would make from the current standard view. It could then be argued that this limited departure a new synchronicbased orthodoxy would make from neoclassicism does not substantially change the nature of economics (though it would involve a genuine departure from neoclassical rational choice microfoundations thinking), since economics would still be largely about choice, albeit as set out in a collection of ideal-type interactive contexts. One might hope that the continual introduction of new concepts in experimental and behavioural game theory increasingly at odds with old neoclassical ones (e.g. various concepts of cognitive processing) might put the process of change in economics on a slippery slope leading to a future economics of interactive individual behaviour quite different in nature, 
but it seems more reasonable to say that the only guarantee that this would occur lies in there being some explicit commitment to evolutionary theorising.

How, then, are we to understand what emerges as heterodoxy on these two views? On the more conservative view, heterodoxy is occupied by neoclassicism, the new diachronic approaches and those traditional heterodox approaches most associated with evolutionary reasoning. On the transformational view, heterodoxy is occupied by neoclassicism, not by the new diachronic approaches nor by any of the traditional heterodox approaches. Indeed, on the transformational view, all three dividing lines between current orthodoxy and heterodoxy are erased, leaving neoclassicism alone in the periphery of economics. This is certainly not to say that differences would not remain between the new research programmes and traditional heterodoxy, particularly with respect to formalism and positivism. But I suggest that these differences would rather be grounds for dissent and disagreement within a new orthodoxy. They could, however, still produce inequities in professional advantages.

The interesting question remaining, consequently, concerns whether traditional heterodoxy might influence the process of change in economics, particularly whether the future pathway is conservative or transformational. Two considerations seem relevant. First, most traditional heterodox economists deny they share any common ground with the new research approaches in economics. Indeed, if one surveys what is published in most traditional heterodox journals, there seems to be limited interest, familiarity and understanding of what these new approaches involve. This stance, on the surface, would seem to make the conservative pathway more likely. Against this, more recently a not insignificant number of heterodox economists have become knowledgeable and interested in the new programmes, especially the diachronic ones, where evolutionary and complexity reasoning draw on traditional heterodox commitments, but also in the behavioural and experimental programmes, as they connect to a longstanding interest in bounded rationality. Second, many traditional heterodox approaches, I believe it can be argued, have adopted an orientation toward the periphery of economics on the grounds that economics needs to be changed through adoption of concepts and principles from other disciplines and social sciences. While I am 
strongly sympathetic to this view of the need for a far-reaching transformation of economics, if these are not the grounds on which economics is in fact changing, then this stance would also make the conservative pathway more likely.

What does this all recommend, then, to traditional heterodox economists? If the argument above is correct regarding the three principles as the common ground of current heterodoxy, then traditional heterodox economists should actively engage with research in the new programmes where its implications advances these principles. This, of course, does not mean supporting everything in the new programmes (indeed old neoclassical commitments and training still influence the new research, if decreasingly so) and, furthermore, the new programmes certainly ignore many important concerns in traditional heterodoxy, so that emphasis needs always to lie on shared ground. But if engagement with the new programmes on this basis is possible, then perhaps it would help make these principles more explicit and central to those programmes. Moreover, since on the transformational view of the future of economics the new diachronic programmes play a key role in contesting neoclassicism, engagement with these programmes in particular offers an important opportunity to increase their relative influence. Traditional heterodoxy, then, seems to have important cards to play.

\section{Economics as a separate science}

Economics has long seen itself since itself as a relatively autonomous science with its own distinctive set of characteristics that make it a 'separate' science (Hausman, 1992). But given that all the new programmes on the research frontier have their origins in other sciences, and import new conceptual contents from outside economics into the field, the status of economics' boundaries and separateness from other fields has become a very real issue. At the same time, economics, as other sciences, has regularly imported other science contents in the past, and having subsequently 'domesticated' them, remade itself still as economics. In the current situation, for example, behavioural economics-a research programme in economics, not in psychology-employs imports from psychology but frames them in terms of economic concerns. Thus, though, historically, sciences do 
sometimes largely pass out of existence, nonetheless there seems to be considerable stability in the long term array of the different sciences (augmented by the rise of new ones) giving us reason to rather believe that from time to time they remodel themselves at least in some degree in the image of other sciences while sustaining their relatively distinctive concerns. If economics, then, remade itself in the image of physics at the turn of the last century (Mirowski, 1989), it may now be remaking itself at the turn of this one in the image of psychology and biology, as reflected in the impetus these fields, respectively, give to the new synchronic and diachronic programmes in economics.

Such a change could be profound and far-reaching, as casual reflection on the difference between modelling social science relationships on physical ones versus natural ones readily suggests. In the current short term, however, this still leaves open what economics' distinctive concerns and indeed its own definition might come to be. Thus, those traditional heterodox research programmes oriented towards economics' boundaries rather than towards its core seem to have one special advantage in a time when the influence of other sciences on economics is strong, since they tend to focus on issues concerning the nature of the field as a whole, which can be neglected by those programmes more dedicated to working out the details of the critique of core orthodoxy. This suggests that a future orthodoxy emergent from current heterodoxy may draw differentially from heterodox research programmes of different orientations based on a division of labour between them. But as the engagement between the new research programmes and traditional heterodox programmes is still quite limited, I leave these issues to future consideration.

The author is also grateful to those attending presentations of the paper at the 2006 History of Economics Society Annual Meeting, the 2007 International Confederation of Associations for Pluralism in Economics Conference, and the 2007 History of Recent Economics Conference.

\section{References:}

Abbott A., The System of Professions: An Essay on the Division of Expert Labor, 1988. Chicago: University of Chicago Press 
Anderson G, Ekelund R, Tollison R. Methodenstreit, The economics of competing interests, European J ournal of the History of Economic Thought, 1992, vol. vol. 8 no 3(pg. 401-18)

Arthur W, Durlauf S, Lane D., The Economy as an Evolving Complex System II, 1997. Reading, Addison-Wesley

Backhouse R. Progress in heterodox economics, Journal of the History of Economic Thought, 2000, vol. vol. 22 no 2(pg. 149-55)

Backhouse R. A suggestion for clarifying the study of dissent in economics, Journal of the History of Economic Thought, 2004, vol. vol.26 no 2(pg. 261-71)

Bourdieu P. Collier P., Homo Academicus, 1988. Palo Alto, Stanford University Press

Bowker G, Starr S., Sorting Things Out: Classification and Its Consequences, 1999. Cambridge, MAMIT Press

Camerer C., Behavioral Game Theory: Experiments in Strategic Interaction, 2003. Princeton, NJ, Princeton University Press

Camerer C, Fehr E. Heinrich J, et al. Measuring Social Norms and Preferences Using Experimental Games: A Guide for Social Scientists, Foundations of Human Sociality, 2004. Oxford, Oxford University Press(pg. 55-95)

Camerer C, Loewenstein G. Camerer C, Loewenstein G, Rabin M. Behavioral Economics: Past, Present, Future, Advances in Behavioral Economics, 2003. Princeton, Princeton University Press

Camerer C, Loewenstein G, Prelec D. Neuroeconomics: How neuroscience can inform economics, J ournal of Economic Literature, 2005, vol. vol 43 (pg.9-64)

Clark A., Being There, 1997. Cambridge, MAMIT Press

Coats A. Garrouste P, Ionnides S. The Progress of Heterodox Economics, Evolution and Path-Dependence in Economic Ideas: Past and Present, 1999. Aldershot, Elgar Colandern, D., Beyond Microfoundations: Post Walrasian Macroeconomics, 1996. Cambridge, Cambridge University Press Colander D. The Death of Neoclassical Economics, J ournal of the History of Economic Thought, 2000, vol. 22 no 2 (pg. 127-44) Colander D. Post Walrasian, Macroeconomics and Heterodoxy:

Thinking Outside the Heterodox Box, International Journal of Political Economy, 2003, vol. 33 no 2(pg. 17-35) 
Colander D. Post Walrasian Macro Policy and the Economics of Muddling Through, International J ournal of Political Economy, 2003, vol. 33 no 2(pg. 68-81)

Colander D, Holt R, Rosser B., The Changing Face of Economics, 2004. Ann Arbor, MI, University of Michigan Press

Collins R., The Sociology of Philosophies: A Global Theory of Intellectual Changes, 1998. Cambridge, MA, Harvard University Press

Cubitt R, StarmerC, Sugden R. Discovered preferences and the experimental evidence of expected utility theory, J ournal of Economic Methodology, 2001, vol. 8 no 3(pg. 385-414)

David P. Clio and the Economics of QWERTY, American Economic Review, 1985, vol. 75 (pg. 332-7)

David P. Dopfer K. Path dependence in economic processes: implications for policy analysis in dynamical systems contexts, The Evolutionary Foundations of Economics, 2005. Cambridge, Cambridge University Press

Davis J., The Theory of the Individual in Economics, 2003. London, Routledge

Davis J. The Turn in Economics: Neoclassical Dominance to Mainstream Pluralism?, J ournal of Institutional Economics, 2006, vol. 2 no 1 (pg. 1-20)

Davis J. Garnett R, Harvey J. Heterodox economics, the fragmentation of the mainstream, and embedded individual analysis, Future Directions in Heterodox Economics, 2007. Ann Arbor, University of Michigan Press

Davis J. Kincaid H, Ross D. Competing conceptions of the individual in recent economics, The Oxford Handbook of the Philosophy of Economic Science, 2008. Oxford, Oxford University Press

Davis J, Sent E-M., 'Heterodoxy's Strategic Pluralism', paper presented at the annual European History of Economics Society meetings, 2006.Portom Portugal

DeMartino G. A Professional Ethics Code for Economists, Challenge, 2005, vol. vol 48 no 4(pg. 88-104)

Dow S. Prospects for the Progress of Heterodox Economics, Journal of the History of Economic Thought, 2000, vol. 22 no (pg. 158-70)

Frey B, Benz M. Davis J, Marciano A, Runde J. From imperialism to inspiration: a survey of economics and psychology, The Elgar 
Companion to Economics and Philosophy, 2004. Cheltenham, Elgar

Friedman D, Cassar A. with contributions from Reinhard Selten and others 2004, Economics Lab: An Intensive Course in Experimental Economics. London, Routledge

Funtowicz S, Ravetz J . Krimsky S, Golding D. Three types of risk assessment and the emergence of post-normal science, Social Theories of Risk, 1992. Westport, CT, Praeger (pg. 251-74)

Gieryn T. Boundary-work and the demarcation of science from nonscience: strains and interests in professional interests of scientists, American Sociological Review, 1983, vol. 48 (pg. 781-95)

Gieryn T. Jasanoff S, Markle G, Petersen J, Pinch T. Boundaries of Science, Handbook of Science and Technology Studies, 1993. Thousand Oaks, CA, Sage. (pg. 393-443)

Gieryn T., Cultural Boundaries of Science: Credibility on the Line, 1999. Chicago, University of Chicago Press

Gintis H. A Framework for the Unification of the Behavioral Sciences, Behavioral and Brain Sciences, 2007, vol. 30 (pg. 161)

Guala F. Building Economic Machines: The FCC Auctions, Studies in the History and Philosophy of Science, 2001, vol. 32 no 3 (pg. 45377)

Hargreaves Heap S, Varoufakis Y. , Game Theory: A Critical Text, 2004 2nd edn London, Routledge

Hausman D , The Inexact and Separate Science of Economics, 1992. Cambridge. Cambridge University Press

Henrich J, Boyd R, Bowles S, Camerer C,Fehr E, Gintis H., Foundations of Human Sociality, 2004. Oxford. Oxford University Press

Holland J., Hidden Order: How Adaptation Builds Complexity, 1995. Reading, MA, Addison-Wesley

Holt R, Pressman S. , Economics and its Discontents: Twentieth Century Dissenting Economists, 1998. Cheltenham, Elgar Kahneman D. Maps of Bounded Rationality: Psychology for Behavioral Economics, American Economic Review, 2003, vol. 935 (pg. 1449-75) 
Kirman A. Rauch J, Casella A. Market Organization and Individual Behavior: Evidence from Fish Markets, Networks and Markets, 2001 New York, Russell Sage. (pg. 155-95)

Lamont M, Molnár V. The Study of Boundaries in the Social Sciences, Annual Review of Sociology, 2002, vol. 28 (pg. 16795)

Lawlor M., The Economics of Keynes in Historical Context: An Intellectual History of the General Theory, 2007. London, Palgrave

Lawson T., Economics and Reality, 1997. London, Routledge

Lawson $T$. The nature of heterodox economics, Cambridge J ournal of Economics, 2006, vol. 30 (pg. 483-505)

Lee F., 'Heterodox Economics', University of Missouri-Kansas City, September 12, Cambridge Journal of Economics, 2006, vol. 31 (pg. 309-325)

Lee F. (forthcoming) The Research Assessment Exercise, the state and the dominance of mainstream economics in British universities, Cambridge Journal of Economics

Mirowski P., More Heat than Light: Economics as Social Physics, Physics as Nature's Economics, 1989. New York, Cambridge University Press

Mirowski P., Machine Dreams: Economics Becomes a Cyborg Science, 2002. New York, Cambridge University Press

Morgan M, Rutherford M., From Interwar Pluralism to Postwar Neoclassicism, 1998. Durham, Duke University Press

Nik-Khah E. What the FCC auctions can tell us about the Performativity thesis, Economic Sociology, 2006, vol. 7 no 2(pg. 15-21)

North D., Institutions, Institutional Change and Economic Performance, 2004. Cambridge, Cambridge University Press

Peart S, Levy D., The 'Vanity of the Philosopher': From Equality to Hierarchy in Post-classical Economics, 2005. Ann Arbor, University of Michigan Press

Plott C. Arrow K, Columbatto E, Perlman M, Schmidt C. Rational individual behavior in markets and social choice processes: the discovered preference hypothesis, The Rational Foundations of Economic Behavior, 1996. Basingstoke, Macmillan(pg. 225-50)

Ravetz J. Clark W, Munn R. Usable knowledge, usable ignorance: incomplete science with policy implications, Sustainable 
Development in the Biosphere, 1986 New York, Cambridge University Press, (pg. 415-32)

Reay M. 'The Uses of Economics', paper presented at the annual History of Economics Society meeting, Grinnell, Iowa, USA, 33rd annual meeting of the History of Economics Society, June 2326, 2006, vol. 200 pg. 6

Rizvi S. Game Theory to the Rescue?, Contributions to Political Economy, 1994, vol. 13 (pg. 1-28)

Samuelson L. Evolution and Game Theory, J ournal of Economic Perspectives, 2002, vol. 16 (pg. 47-66)

Samuelson L. Economic Theory and Experimental Economics, J ournal of Economic Literature, 2005, vol. 43 (pg. 65-107)

Sent E-M. Behavioral Economics: How Psychology Made Its (Limited)

Way Back Into Economics, History of Political

Economy, 2004, vol. 36 (pg. 737-62)

Smith V. Theory, Experiment and Economics, J ournal of Economic

Perspectives, 1989, vol. 3 no 1(pg. 151-69)

Smith V. Economics in the Laboratory, J ournal of Economic

Perspectives, 1994, vol. 8 (pg. 113-31)

Smith V. Nadel L. Experimental Methods, Cognitive Science Encyclopedia, 2003. London, Nature Publishing (pg. 1070-79) Economics

Starmer C. Developments in Non-Expected Utility Theory: The Hunt for a Descriptive Theory of Choice under Risk, J ournal of Economic Literature, 2000, vol. 38 (pg. 332-82)

Sunstein C, Thaler R. Libertarian Paternalism Is Not An Oxymoron, University of Chicago Law Review, 2003, vol. 70 no 4, (pg. 1159-202)

Tajfel H, Turner J. Worchel S, Austin W. The Social Identity Theory of Intergroup Behavior, Psychology of Intergroup Relations, 1985. Chicago, Nelson-Hall

Tesfatsion L. Structure, Behavior, and Market Power in an Evolutionary Labor Market with Adaptive Search, Journal of Economic Dynamics and Control, 2001, vol. 25 (pg. 419-57)

Testfatsion L. 'Agent-Based Computational Economics: A Constructive Approach to Economic Theory', I owa State University working paper, 200531 March

von Neumann J, Morgenstern O., The Theory of Games and Economic Behavior, 1944. Princeton, Princeton University Press 
NOT THE PUBLISHED VERSION; this is the author's final, peer-reviewed manuscript. The published version may be accessed by following the link in the citation at the bottom of the page.

Young W., Interpreting Mr. Keynes, 1987. Westview. Boulder, CO

${ }^{1}$ I do not investigate the fragmentation of dominant approaches and te rise of pluralism here, because my focus is on possible convergences in the new research approaches in economics. However, three perhaps complementary theories about why the postwar dominance of the neoclassical research programme has generated conditions for the rise of the new research programmes in economics are summarised in Davis (2006).

${ }^{2}$ This paper was widely circulated before publication, and is published with a collection of commentaries.

${ }^{3}$ Though the sociological concept of symbolic boundaries dates back to the nineteenth century, its application in research on the nature of academic disciplines and the professions dates from the 1980s and in-group versus out-group social identity analysis as developed by Tajfel and Turner (1971). Lamont and Molnár (2002) provide a recent, comprehensive survey of this literature. Influential contributions include those of Abbott (1988), Bourdieu (1988), Bowker and Starr (1999), Collins (1998), and especially (Gieryn 1983, 1993, 1999).

${ }^{4} \mathrm{An}$ alternative, more enlightened, direct form of defence of economic policy would be for economics to join other sciences and disciplines in adopting a professional code of ethics (DeMartino, 2005).

${ }^{6}$ For example, all appear to work with alternatives to the atomistic individual conception, a foundational assumption in neoclassical economics (cf. Davis, 2008).

${ }^{7}$ Here I largely agree with Colander (2003A, 2003B).

${ }^{8}$ Thus from 1950 to 1990 neoclassical economics was orthodox in capitalist economies and heterodox in socialist economies, while Marxist economics was orthodox in socialist economies and heterodox in capitalist economies.

${ }^{9}$ See Davis and Sent (2006) for fuller discussion of heterodox origin stories.

${ }^{10}$ There is a Chicago School tradition in evolutionary thinking, but its focus is on an 'as if' justification of rational behaviour in the form of an outcome of a past evolutionary process, whereas the

Cambridge Journal of Economics, Vol 32, No. 3 (May 2008): pg. 349-366. DOI. This article is (C) Oxford University Press and permission has been granted for this version to appear in e-Publications@Marquette. Oxford University Press does not grant permission for this article to be further copied/distributed or hosted elsewhere without the express permission from Oxford University Press. 
NOT THE PUBLISHED VERSION; this is the author's final, peer-reviewed manuscript. The published version may be accessed by following the link in the citation at the bottom of the page.

new evolutionary programmes are focused on evolutionary systems themselves.

${ }^{11}$ See the ICAPE associates (www.icape.org) for a much longer list.

${ }^{12}$ See the charter of the International Confederation of Associations for Pluralism in Economics (www.icape.org). All eight traditional approaches identified above are represented in ICAPE. Many post-Keynesians and neo-Ricardians, however, accept the dominance view.

${ }^{13}$ Tesfatsion, for example, asserts that the term agent 'refers broadly to bundled data and behavioural methods representing an entity constituting part of a computationally constructed world. Examples of possible agents include individuals (e.g. consumers, workers), social groupings (e.g. families, firms, government agencies), institutions (e.g. markets, regulatory systems), biological entities (e.g. crops livestock, forests) and physical entities (e.g. infrastructure, weather, geographical regions) (Tesfatsion, 2005, p. 6).

${ }^{14}$ I ndeed, Smith largely packs evolutionary arguments into the past by employing arguments from evolutionary psychology to explain individuals' current choice behaviour as an outcome of evolution rather than part of an on-going evolutionary process (Smith, 2003). 